\title{
Review
}

\section{The future of the oceans past}

\author{
Jeremy B. C. Jackson ${ }^{1,2, *}$ \\ ${ }^{1}$ Center for Marine Biodiversity and Conservation, Scripps Institution of Oceanography, \\ La Folla, CA 92037, USA \\ ${ }^{2}$ Smithsonian Tropical Research Institute, PO Box 2072, Balboa, Republic of Panama
}

\begin{abstract}
Major macroevolutionary events in the history of the oceans are linked to changes in oceanographic conditions and environments on regional to global scales. Even small changes in climate and productivity, such as those that occurred after the rise of the Isthmus of Panama, caused major changes in Caribbean coastal ecosystems and mass extinctions of major taxa. In contrast, massive influxes of carbon at the end of the Palaeocene caused intense global warming, ocean acidification, mass extinction throughout the deep sea and the worldwide disappearance of coral reefs. Today, overfishing, pollution and increases in greenhouse gases are causing comparably great changes to ocean environments and ecosystems. Some of these changes are potentially reversible on very short time scales, but warming and ocean acidification will intensify before they decline even with immediate reduction in emissions. There is an urgent need for immediate and decisive conservation action. Otherwise, another great mass extinction affecting all ocean ecosystems and comparable to the upheavals of the geological past appears inevitable.
\end{abstract}

Keywords: marine ecosystems; human impacts; extinction; climate change; palaeoceanography

\section{INTRODUCTION}

Life in the oceans has always been a story of fits and starts. Varyingly long periods of comparative environmental stability or gradual change over millions of years have been repeatedly punctuated by ecological and evolutionary revolutions set off by geologically rapid shifts in environmental conditions or by catastrophic events (Zachos et al. 2001, 2008; Knoll 2003). The frequency and magnitude of biological changes observed vary with the intensity and duration of oceanographic change and the level of taxonomic resolution and geographical scale of analysis. Now we are entering an era of massive anthropogenic environmental changes that have greatly altered marine communities and threaten entire marine ecosystems. Moreover, there is every indication that the intensity of disturbance will continue to accelerate in the immediate future, with ecological and evolutionary consequences that will soon rival the changes associated with the strongest perturbations of the last 65 million years (Myr).

The geological record provides a valuable frame of reference for gauging the magnitude, consequences and potential irreversibility of human impacts on the oceans; but with the important proviso that many aspects of the current situation are without natural precedent. Here, I will first review the fossil record of two periods of environmental and biological changes of very different intensity: (i) changes in

*jbjackson@ucsd.edu

One contribution of 16 to a Discussion Meeting Issue 'Biological diversity in a changing world'.
Caribbean ecosystems owing to oceanographic changes associated with the rise of the Isthmus of Panama between 4 and 3 million years ago ( $\mathrm{Ma}$ ) and (ii) sudden and dramatic global changes in deep-sea communities, phytoplankton and coral reefs associated with the spike in ocean acidification during the Palaeocene-Eocene thermal maximum (PETM) $55 \mathrm{Ma}$. The Caribbean example is based on research of myself and colleagues in the Panama Palaeontology Project, and is discussed in some detail to emphasize how quite small changes in oceanographic conditions comparable to those that have already occurred owing to human activities have resulted in profound historical changes in ecosystem structure and function as well as the regional mass extinction of major taxa. The PETM example is presented more briefly because it has been reviewed in detail elsewhere (Zachos et al. 2008). The main point is to emphasize the apocalyptic consequences that have occurred repeatedly in the deep past owing to geologically instantaneous increases in $\mathrm{CO}_{2}$ comparable to what would occur within a few centuries if all known oil and coal reserves were burned in a business-as-usual scenario.

Next, I will summarize the very considerable and rapidly intensifying human impacts on ocean ecosystems owing to exploitation, pollution and climate change that I have reviewed in more detail elsewhere (Jackson et al. 2001; Jackson 2008). The main point is that different kinds of human disturbance act synergistically so that the sum total of their ecological consequences exceeds that of their effects in isolation.

I will conclude with a series of ecological scenarios for the oceans over the next few decades to a century if humanity fails to change its course. My purpose is to 
emphasize the overwhelming strength of the scientific evidence for the trends that are taking place but have so far failed to capture the attention of governments or society. Without such awareness, the inevitably enormous social and economic changes required to slow down or partially reverse the trends will be impossible.

\section{PALAEOBIOLOGICAL PERSPECTIVE}

The great revolutions in the history of life of the oceans are correlated with major changes in environmental conditions, although in most cases we are just beginning to decipher the underlying mechanisms of change (Knoll 2003; Jackson \& Erwin 2006). Environmental factors believed to be responsible include persistent shifts in temperature, productivity, circulation patterns and oxygen availability; periods of intense volcanism; variations in the eccentricity, obliquity and precessions of the Earth's orbit around the sun (Milankovitch cycles); as well as more sudden, episodic events associated with major disruptions of global biogeochemical cycles or asteroid impact (Knoll 2003; Zachos et al. 2008; Kump et al. 2009). Formulations of testable hypotheses about the processes responsible for episodes of intense evolutionary change, and the development of new programmes of fieldwork and data collection specifically designed to test them, are a major research agenda in palaeobiology today (Jackson \& Erwin 2006).

\section{(a) Shallow-water Caribbean ecosystems over the past $10 \mathrm{Myr}$}

The most recent burst of ecological and evolutionary change in the oceans occurred approximately $2 \mathrm{Ma}$ (Stanley 1986; Smith \& Roy 2006; Smith \& Jackson 2009). Biological changes coincide with global cooling owing to the intensification of Northern Hemisphere glaciation and major oceanographic changes owing to the isolation of the Atlantic from the Pacific by the closure of the Panamanian seaway between North and South America (Coates et al. 1992; Jackson et al. 1996; Haug \& Tiedemann 1998; Budd \& Johnson 1999; Bartoli et al. 2005).

The geologically well-documented rise of the Isthmus of Panama and consequent isolation of the Caribbean from the tropical eastern Pacific (TEP) provides a model system to test hypotheses of cause and effect for marine benthic communities in the southwestern Caribbean (SWC) over the past $10 \mathrm{Ma}$ (Jackson et al. 1996; O’Dea et al. 2007). Biological communities and environmental conditions are profoundly different on opposite sides of the Isthmus today (Jackson \& D'Croz 1997), which begs the question when the differences arose and what were the processes responsible. To answer these questions, my colleagues and I in the Panama Palaeontology Project surveyed benthic communities on both sides of the Isthmus and compared these with long-term environmental monitoring data. We then looked back in time in the SWC to measure changes in environments and biotas based on environmental proxies and the relative abundance of major taxa in quantitative samples spanning the last $10 \mathrm{Myr}$. Faunal changes closely tracked evidence for collapse in upwelling and planktonic productivity associated with the emergence of the Isthmus. Ecological and life-history characteristics of taxa that survived these changes versus those that became extinct support the hypothesis that collapse in productivity was the major agent of change.

The TEP exhibits strong seasonal fluctuations in temperature and upwelling, high planktonic productivity, abundant suspension feeders, small and ephemeral coral reefs and absence of seagrasses (D'Croz \& Robertson 1997; Jackson \& D'Croz 1997; D'Croz et al. 2005; D'Croz \& O’Dea 2007). By contrast, the SWC exhibits low seasonality, upwelling and planktonic productivity, fewer suspension feeders and abundant coral reefs and seagrasses. Species diversity is also much higher in the SWC than in the TEP. Differences in ecological community composition are well described by the relative abundance of skeletal remains in sediments of major shelly taxa including bivalve and gastropod molluscs, scleractinian corals, bryozoans and calcareous algae (O'Dea et al. 2007). Differences in oceanographic conditions and productivity are reflected in the per cent carbonate in sediments and the mean annual range in temperature (MART) derived from changes in the average size of feeding zooids of cheilostome bryozoans throughout the life of individual colonies (O'Dea \& Jackson 2002; O'Dea et al. 2007).

Ordination of recent assemblages based on the relative abundance of major taxa demonstrates clear separation of biotas from the two oceans (O'Dea et al. 2007). The first principal component PCA1 explains 62 per cent of the biotic variation and reflects dominance of TEP localities by bivalves and gastropods versus corals and calcareous algae in the SWC. These differences are driven by opposite trends of MART and per cent carbonate. Thus, the first principal component describes a trophic gradient along which predominance of heterotrophs corresponds to high MART and that of mixotrophs and autotrophs to high carbonate.

Inclusion of fossil faunas in the ordination demonstrates a striking transition in community composition in the SWC over the past $10 \mathrm{Myr}$ from dominance of assemblages by bivalves and gastropods comparable to the TEP today to modern SWC biotas with increased abundance of corals and calcareous algae (figure 1d). Most of this change occurred between about 4.25 Ma when the connection between the oceans was nearly severed and about $3.45 \mathrm{Ma}$ when isolation was complete. PCA1 explains 57 per cent of the biotic variations and is driven by a collapse in productivity reflected by a precipitous drop in MART and increase in carbonate. The causal relation between community composition and environmental change is strongly supported by linear regressions between PCA1 and MART and per cent carbonate from the same samples $\left(r^{2}=-0.52\right.$ and $0.42, p<$ 0.001 in both cases).

Faunal turnover was also associated with major peaks in extinction of reef corals, molluscs (principally gastropods) and major taxa of cheilostome bryozoans (figure 1; Budd \& Johnson 1999; Todd et al. 2002; O’Dea \& Jackson 2009; Smith \& Jackson 2009). 


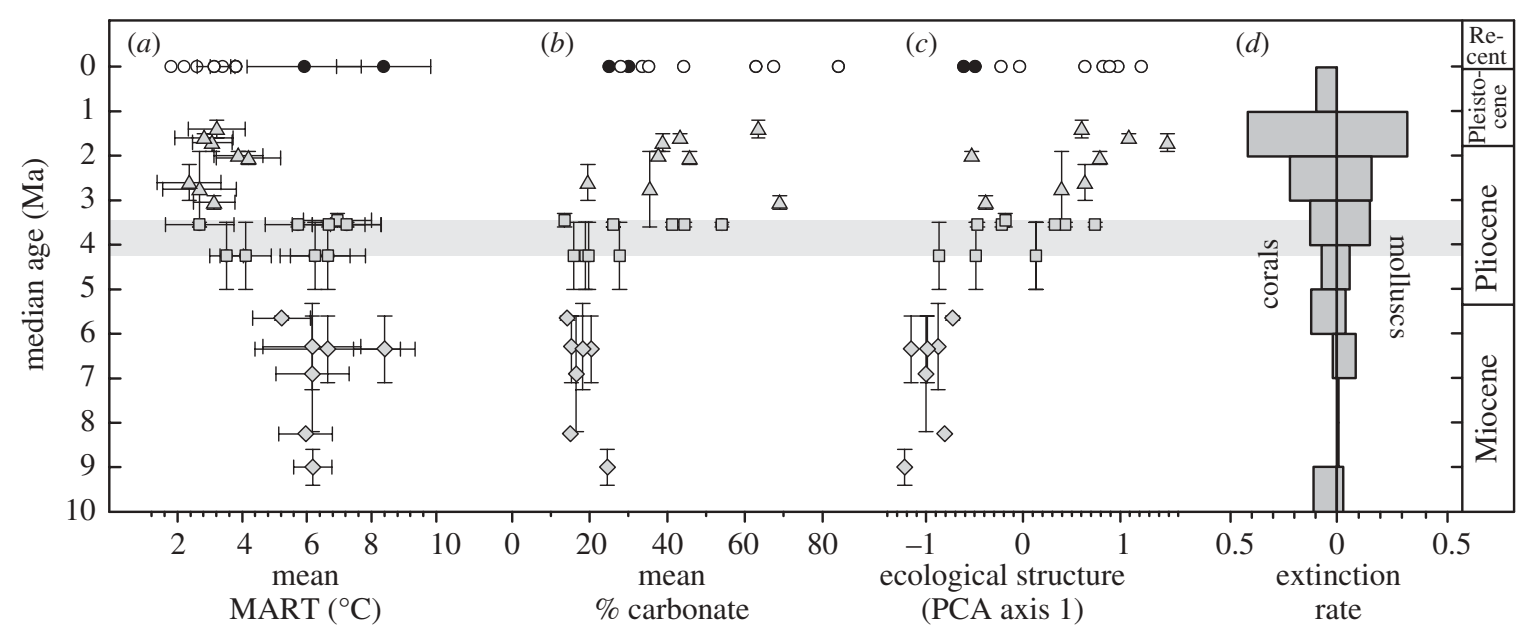

Figure 1. Chronology of environmental and ecological changes in the coastal SWC over the last 10 Myr. (a) Ecological structure of biotic assemblages estimated by PCA axis $1,(b)$ per cent carbonate in sediments, $(c)$ MART and $(d)$ extinction rates for coral species and molluscan genera. Environmental change is concentrated in the period of the final closure of the Panamanian Strait about 4.4-3.5 Ma, whereas peaks in extinction lagged by 1-2 Myr. Horizontal error bars indicate $95 \%$ confidence intervals and vertical bars indicate maximum and minimum age estimates of collections. Adapted from O'Dea et al. (2007).

Extinction of bivalves closely tracked changes in environmental conditions but extinction of gastropods, corals and cupuladriid bryozoans dragged out over 2 Myr. The cause of the lag in extinction is still unresolved, but there is considerable evidence that species destined for extinction hung on in local metapopulations long after their overall abundance had declined compared with populations of surviving or newly evolved species (O’Dea \& Jackson 2009; Smith \& Jackson 2009).

The hypothesis that decreased productivity was the major factor in ecological turnover and extinction is supported by independent ecological, morphological and life-history data. First, development of extensive tracts of coral reefs greatly increased after the drop in productivity despite the extinction of 50 per cent of Caribbean coral species at the same time (Johnson et al. 2008). This pattern is consistent with the wellestablished global pattern of greatest reef development in areas of low upwelling and productivity. Second, the relative abundance of suspension-feeding and predatory molluscs declined relative to grazing, depositfeeding and chemoautotrophic molluscs as expected from a drop in productivity (Todd et al. 2002). Third, life-history patterns of scallops and cupuladriid bryozoans shifted markedly in accordance to predictions of life-history theory (J. T. Smith 2007, unpublished data; O'Dea \& Jackson 2009).

Decreased productivity and seasonality should result in an increase in egg size and a shorter freeliving larval phase (Roughgarden 1971; Vance 1973; McEdward 1997; Levitan 2000). We can test these predictions for scallops because the larval shell is often preserved on fossils and the size of the first stage of the larval shell (PI) is significantly correlated with egg size, while the size of the second larval shell (PII) is correlated with the duration of the free-swimming larval stage (J. T. Smith 2007, unpublished data). Data were obtained for 1611 PII shells and 481 PI shells that are less commonly preserved as fossils. As predicted, PI size increased and PII size decreased during the period of the drop in Caribbean productivity. PII size is also significantly correlated with per cent carbonate and MART, so that the same factors that drove community change also drove life-history evolution.

Decreased productivity should also result in decreased asexual or clonal reproduction because cloning requires rapid growth and abundant food (Winston 1977; Hakansson \& Thomsen 2001; O'Dea 2006). The reproductive origin of cupuladriid bryozoans is clearly apparent in their patterns of budding and colony growth, which is symmetrical with uninterrupted budding patterns in colonies that originated from sexually produced larvae, versus asymmetrical growth with irregular budding and scars in colonies that originated by clonal processes such as fragmentation or colony budding (McKinney \& Jackson 1989; O'Dea et al. 2004, 2008). The clonal or aclonal origin for nearly 150000 fossil and recent colonies of 24 common species was determined from samples spanning the last $10 \mathrm{Myr}$ (O'Dea \& Jackson 2009). The frequency of clonal colonies greatly declined from a median of 70 per cent prior to the drop in productivity to just 11 per cent afterwards (figure 2). Rates of clonal reproduction declined significantly among the 13 extant species, whereas none of the 13 species that became extinct exhibited a decrease in clonal reproduction. Thus, the overall trend resulted from increased origination of predominantly aclonal species, extinction of species that failed to reduce rates of clonality and strong reduction in clonality of older surviving species.

In summary, moderate changes in oceanographic conditions, no greater than those observed across the Isthmus of Panama today, were sufficient to set off profound ecological reorganization of marine communities, spikes in extinction and origination of species and shifts in life histories of common taxa.

\section{(b) Palaeocene-Eocene thermal maximum}

The PETM was the strongest of several early Cenozoic intervals of extreme global warmth and massive release 

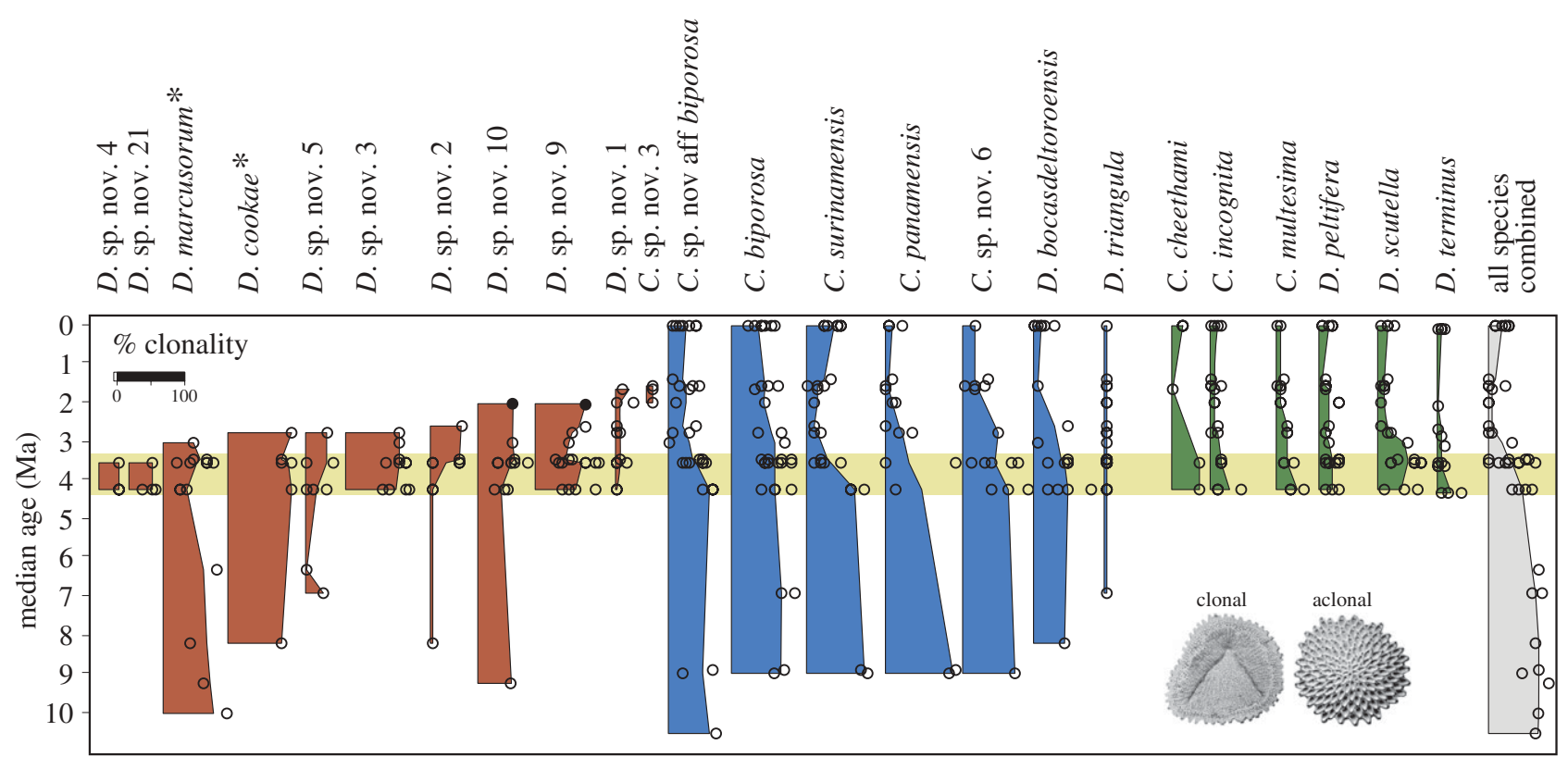

Figure 2. Life histories of 24 common cupuladriid bryozoan species responded to environmental change (horizontal yellow bar) in the SWC. As planktonic productivity collapsed, species that survived significantly reduced their levels of clonal reproduction, while newly originated species were all predominantly aclonal. By contrast, species that failed to reduce levels of clonal reproduction became extinct 1-2 Ma after the environment changed, except for two species, indicated by asterisks in the figure, that survived in the eastern pacific (red). Thickness of the vertical range bar for each species represents the percentage of clonal colonies. Data for all species combined (grey/far-right bar) were calculated as the percentage of all clonal colonies irrespective of species. Note that $0 \%$ clonality is shifted slightly to the right to give entirely aclonal values some thickness. Adapted from O’Dea \& Jackson (2009).

of carbon lasting only a few tens of thousands of years (Zachos et al. 2008; Kump et al. 2009). The evidence for sudden environmental change is twofold. First, sharp decreases in the ratio of ${ }^{13} \mathrm{C} /{ }^{12} \mathrm{C}$ of both carbonate and organic carbon in marine sediments reflect the release of huge amounts of ${ }^{13} \mathrm{C}$-depleted carbon into the atmosphere or oceans. Second, very large decreases in deep-sea carbonates signify ocean acidification and dissolution at several thousand metres depth. Global temperature increased by more than $5^{\circ} \mathrm{C}$ even at the poles, and more than $2000 \mathrm{Gt}$ of carbon entered the oceans as $\mathrm{CO}_{2}$ in less than $10 \mathrm{kyr}$ (Zachos et al. 2008). Vertical overturning of the ocean and the supply of dissolved oxygen to the deep sea decreased as evidenced by laminated sediments in deep-sea ocean cores.

The sources of such massive amounts of carbon and the degree of $\mathrm{CaCO}_{3}$ saturation are still controversial, as are the details of the ocean warming in the tropics and the extent to which the surface ocean was buffered by dissolution in the deep sea (Zachos et al. 2008; Kump et al. 2009). But the extreme ecological consequences are obvious. Deep-sea benthic foraminifera suffered their greatest mass extinction within the last $93 \mathrm{Myr}$ when some $30-50 \%$ of species became extinct within $10-20 \mathrm{kyr}$, owing to some as-yet unresolved combination of acidification, warming and anoxia (Thomas \& Shackleton 1996; Thomas 1998, 2007). At the same time, communities of calcareous nannoplankton in the surface ocean underwent rapid changes in the relative abundance of major taxa (Bralower 2002; Gibbs et al. 2006a,b). Large coral reef tracts also disappeared and were replaced by banks of larger foraminifera with scattered individual corals, a response to warming or acidification or some combination of both (Scheiber \& Speijer 2008).
In summary, massive changes in the rates and amounts of carbon introduced into the oceans and atmosphere at the start of the PETM were associated with mass extinction, restructuring of ocean food webs and the disappearance of coral reefs on a global scale.

\section{HISTORICAL AND RECENT HUMAN IMPACTS ON OCEAN ECOSYSTEMS}

Humans exploited the oceans almost from the beginnings of our species and left little garbage heaps of seashells and bones to prove it. Fishing greatly intensified several thousand years ago when the rubbish heaps increased in size and number as did the sizes of species consumed, and our efforts began to take a toll (Erlandson \& Rick 2010). By the time of the Romans, most of the large Mediterranean species were greatly diminished and the Romans expanded their fishing grounds from the far shores of the black sea to Britain to meet their needs. Similar patterns are evident in the Americas where bursts in exploitation were followed by decreases in the sizes and abundance of exploited species (Hardt 2008).

Five hundred years ago, the expansion of the great European maritime empires brought new technologies and opened up the entire ocean to exploitation with boom and bust cycles of fishing for shellfish, fish, turtles, sea birds, seals, sea cows and whales (Roberts 2007). But the real damage began when what had previously been a series of local to regional problems became truly global in extent, driven by the modern economic passion for growth and seemingly endless supplies of cheap energy from fossil fuels. Since then, the oceans as we knew them have begun to die, 
with dramatic declines in coral reefs, seagrasses, kelp forests, mangroves, marshes, estuaries and coastal seas, continental shelf ecosystems and even the deep sea (Jackson 2001, 2008; Jackson et al. 2001; Gardner et al. 2003; Pandolfi et al. 2003; Lotze et al. 2006; Waycott et al. 2009).

The three main drivers of the modern degradation of the oceans are overexploitation, pollution in all its myriad forms and the rise of carbon dioxide owing to the burning of fossil fuels - the ultimate mega-pollutant of them all. I will first briefly review some of the most striking consequences for the oceans and then discuss the mounting consequences of their synergistic effects.

\section{(a) Exploitation}

Most marine mammals and all sea turtles are severely threatened or on the verge of extinction, although many whales have recovered substantially following the increasingly precarious moratorium on whaling (Whitehead 2002; Stevick et al. 2003; McClenachan et al. 2006; Alter et al. 2007; McClenachan \& Cooper 2008; Lotze \& Worm 2009). Virtually, all industrial fisheries are fully exploited or overfished, and fisheries in general are in serious decline (Jackson et al. 2001; Pauly et al. 2002; Myers \& Worm 2003; Worm et al. 2009). The greatest losses are in the Mediterranean and North Atlantic where legendarily abundant stocks of cod and other groundfish, billfish, tuna, herring and all large shark species are effectively ecologically extinct (Baum et al. 2003; Christensen et al. 2003; Safina \& Klinger 2008). The situation is better in the Pacific, but overfished salmon have collapsed throughout most of the Pacific northwest, most tuna and billfish are fished to capacity or overfished and the last great US fishery of East Bering Sea pollock is showing dangerous signs of collapse (Morell 2009) despite being one of the most intensively researched and managed fish stocks in the world (NOAA 2008; Ianelli et al. 2009).

Recreational fishing has also taken an increasingly heavy toll with severe overfishing of popular species (McPhee et al. 2002; Coleman et al. 2004; McClenachan 2009a,b). Even the once fantastically abundant California sardines and Peruvian anchoveta were severely overfished until strict management allowed stocks to recover (McCall 2011). In general, fisheries for invertebrates such as scallops, crabs, shrimp and lobster are replacing fisheries for large, previously favoured fish species.

Most industrial fisheries also have varyingly severe impacts on unwanted and discarded species, termed bycatch, as well as direct and indirect destructive impacts on the environment (Dayton et al. 1995; Lewison et al. 2004; NRC 2002, 2006; Ward \& Myers 2005). The worst impacts are due to trawling and dredging, which level and transform the complex underwater forests of sponges, corals and shellfish on the sea floor to level plains of mud, indiscriminately capturing all the species on the bottom, most of which are discarded. Discard rates for shrimp or Orange Roughy may exceed 99 per cent. Most of the sea floor in the North Sea, the continental shelves of the Atlantic and Gulf coasts of the United States and the continental shelves of Southeast Asia are swept clean by trawling every year, with many areas trawled several times a year (NRC 2002). Other forms of fishing have less direct impacts on the sea floor, but have horrific rates of bycatch. The worst are driftnets (internationally banned but still used by pirate fishers), followed by gillnets, long-lines, mid-water trawls (that commonly strike the bottom causing comparable damage to bottom trawling) and purse seines. Longlines kill enormous numbers of sea turtles, large sharks and albatrosses every year (Lewison et al. 2004) while purse seines used to catch tuna take a similar toll on dolphins. The nets are set on dolphins that swim with tuna, causing the dolphins to drown. New technologies allow most of the dolphins to escape, but these are not universally employed (Gerrodette 2002). Moreover, the trauma of repeated capture has resulted in reproductive decline, so that dolphins are not recovering as expected (Cramer et al. 2008).

Overfishing of predators commonly allows unchecked increases of their former prey (Estes et al. 1998; Frank et al. 2005; Baum \& Worm 2009). The most spectacular recent example is the population explosion of cow-nosed rays in the western Atlantic following the decimation of hammerhead sharks by 99 per cent since the 1980s (Baum et al. 2003; Myers et al. 2007). As a result, schools of millions of the rays now consume vast quantities of shellfish, destroying the scallop fishery in the process. Likewise, overfishing of sea otters and other predators sets off population explosions of sea urchins that transform kelp forests into sea urchin barrens of bare rock and crustose algae (Simenstad et al. 1978; Estes et al. 1989; Witman \& Sebens 1992), whereas overfishing of herbivorous fishes or sea urchins commonly causes population explosions of seaweeds that overgrow benthic communities formerly dominated by reef corals, sponges or other complex assemblages of invertebrates (Hughes 1994; Hughes et al. 2010). In general, coral reefs are extremely overfished, with fish biomass commonly reduced to less than $40-100 \mathrm{~g} \mathrm{~m}^{-2}$ fish on heavily populated coasts compared with greater than $250-1000 \mathrm{~g} \mathrm{~m}^{-2}$ on reefs long protected from fishing (Jackson 2008; Knowlton \& Jackson 2008; Sandin et al. 2008).

\section{(b) Pollution}

All the different forms of garbage, sewage and toxic wastes of humanity are polluting the oceans at ever increasing rates. Among the most important-other than carbon dioxide emissions from fossil fuels, which I will discuss separately-are exotic species, toxins, plastics and nutrients.

Introductions of exotic species and their ecological consequences are rapidly increasing owing to increased shipping traffic, which includes routine dumping of hundreds of thousands of gallons of ballast water from one ocean into another; deliberate introductions; and anthropogenic warming that has shifted species' geographical distributions by hundreds to thousands of kilometres (Carlton \& Geller 1993; Stachowicz 
et al. 2002; Parmesan 2006; Molnar et al. 2008). Exotic species are common pests in 84 per cent of the world's ocean regions, and are especially abundant in estuaries and coastal seas where they increasingly displace native species, alter community structure, diminish fisheries and foul and clog structures at enormous economic cost (Lotze et al. 2006; Molnar et al. 2008).

One spectacular example is the alga Caulerpa taxifolia that was accidentally introduced from an aquarium into the northwest Mediterranean in the 1980s and aggressively overgrows most native species of near-shore bottom-dwelling animals and plants that are in steep decline (Meinesz 1999; Piazzi et al. 2001). Pacific lionfish are another beautiful aquarium species that was accidentally or deliberately introduced into the tropical western Atlantic sometime in the 1990s or 2000s. Lionfish have already spread throughout the entire region where they have reached local abundances an order of magnitude greater than in their native Pacific and consume the majority of larval fish recruits of native species (Albins \& Hixon 2008; Coté \& Maljkovie 2010). Introduced jellyfish have exploded in areas like the Black Sea and Gulf of Mexico where they consume swimming larval stages of commercially important fishes whose populations decline precipitously or fail to recover from depletion owing to overfishing or severe El Niño events (Lynam et al. 2006; Daskalov et al. 2007).

Oil spills are the most familiar causes of toxic pollution in the ocean. Spills range in volume from small events of a few million litres to the spectacular 2010 blow-out of the Deepwater Horizon well that released $0.5-1$ billion litres. Even small spills can cause considerable ecological destruction. A coastal spill in Panama of about 8 million litres killed $100 \mathrm{~km}$ of mangroves, seagrasses and coral reefs in 1986, with only limited subsequent recovery (Guzmán et al. 1991; Jackson et al. 1989). Recovery from the notorious Exxon Valdez spill in Alaska has also been variable and incomplete (Peterson et al. 2003).

Nevertheless, ecologically harmful effects of pollution from non-point sources of urban, industrial and agricultural run-off are much greater than oil spills (Carpenter et al. 1998). The best known toxins are PCBs and mercury, which are increasingly bioaccumulated up the food chain to highly toxic levels in apex predators and the people who consume them (Booth \& Zeller 2005; Campbell et al. 2005). Most of the mercury in the oceans is derived from the exhaust of coal-fired power plants that is dispersed in the upper atmosphere and shunted towards the poles where it descends to the oceans (Carpi 1997). In contrast, contamination of PCBs and agricultural pesticides is highest in coastal waters nearer to the sources of pollution (Bush et al. 1989; Burreau et al. 2006).

Plastic debris is accumulating in the oceans at a staggering rate with consequences that are only beginning to be understood (Azzarello \& Van Fleet 1987; Derraik 2002; Weiss \& McFarling 2006). Effects of large, visible material are obvious from the enormous concentrations of plastics drifting in ocean gyres that may extend for thousands of kilometres, and the plastic litter on the shores of islands in their path. Plastics cause the deaths of untold numbers of seabirds like albatrosses whose entire digestive tracts, and those of their young they feed, become stuffed with plastics before they eventually die. There are also increasing concentrations of barely visible to microscopic particles derived from the physical and chemical breakdown of some plastics in sea water (Moore et al. 2001). Many of these tiny particles are the same size as plankton fed upon by grazing animals that subsist by filtering sea water for their food, and thus may severely hamper their nutrition. Chemicals leached from plastics in sea water may also pose a toxic threat by analogy with health warnings on plastic containers of food and water for human consumption.

Pollution of coastal waters by petroleum-based fertilizers, animal wastes from industrial-scale hog and chicken farms and human sewage has greatly increased since the 1950s, with devastating effects on coastal ecosystems (Rabalais et al. 2002, 2007; Galloway et al. 2004; Lotze et al. 2006; Diaz \& Rosenberg 2008). The excess nutrients from these sources fuel explosive growth of photosynthetic plankton out of all proportion to the capacity of suspension-feeding animals to consume them-especially since the extreme overfishing of oysters and menhaden that constituted a highly efficient natural filter (Jackson et al. 2001). The problem is particularly great for population explosions of small microbial phytoplankton, whose cells are too small to be consumed by most suspension feeders like copepods, oysters and menhaden, but sustain population explosions of unwanted jellyfish. Excess phytoplankton dies and sinks to the bottom where it is broken down by microbes, consuming most or all of the oxygen above the seafloor in the process. Bottom-dwelling animals that cannot move away are asphyxiated and die (Vaquer-Sunyer \& Duarte 2008).

The resulting 'dead zones' such as those in the Baltic and Adriatic Seas, Chesapeake Bay and northern Gulf of Mexico extend for hundreds of kilometres (Rabalais et al. 2002, 2007; Diaz \& Rosenberg 2008). The number of reported dead zones worldwide has increased from about 125 in the 1990s to more than 500 today, an increase that may in part reflect greater awareness and effort to record them. But such diligence cannot explain the considerable increases in size and duration of hypoxia for historically well-documented dead zones in places like the Gulf of Mexico and Chesapeake Bay-many of which are in areas that once supported highly productive fisheries that have been replaced by jellyfish (Rabalais et al. 2002; Lynam et al. 2006). Dead zones are also the sites of increasingly frequent outbreaks of toxic dinoflagellates, popularly called 'red tides', that kill fish and marine mammals, poison shellfish and fill hospitals with people suffering from respiratory distress (Weiss \& McFarling 2006). Run-off of excess fertilizer can also cause population explosions of seaweeds, as for the green alga Ulva piling up on the beaches of Brittany and causing deaths of seabirds, livestock and people (Le Télégramme 2009). 


\section{(c) Rise in carbon dioxide}

The rapidly increasing concentration of $\mathrm{CO}_{2}$ and methane $\left(\mathrm{CH}_{4}\right)$ in the atmosphere owing to combustion of fossil fuels and industrial animal production is a vast, uncontrolled geophysical experiment (Revelle \& Seuss 1957) that is warming the planet and making the oceans more acidic, with increasingly dire implications for natural ecosystems and humanity (Stern 2006). The effects of warming are straightforward. Arctic summer sea ice is melting much more rapidly than expected from climate model predictions (Stroeve et al. 2007) and may disappear entirely in 10-20 years, posing grave threats to virtually all high Arctic ecosystems as well as species dependent on summer ice such as polar bears. Sea ice is also rapidly disappearing in the Antarctic with reductions in krill and the species that feed upon them (Brierley et al. 2002; Atkinson et al. 2004). We can only guess at the numbers of species doomed to go extinct as entire polar ecosystems disappear, as well as from the equatorial tropics that will soon be hotter than in the previous several million years. Species are rapidly shifting poleward (Beaugrand et al. 2002; Southward et al. 2005; Field et al. 2006). One of the most spectacular examples is the large, predatory Humboldt squid (Dosidicus gigas), which has extended its northern range from the Gulf of California to southern Alaska in the past 30 years and is now one of the most important fisheries in California (Zeidberg \& Robison 2007; Keyl et al. 2008).

Warming of tropical seas also causes massive bleaching and death of reef corals owing to the breakdown in the symbiosis between corals and the symbiotic dinoflagellates that provide sugar to their hosts. The symbionts are expelled by the corals when temperatures rise just $1-2^{\circ} \mathrm{C}$ above maximum levels prior to global warming, whereupon the corals subsequently die unless they become reinfected by symbionts (Knowlton 2001; Hughes et al. 2003; Hoegh-Guldberg et al. 2007). The exceptional El Niño of 1998 caused up to 80 per cent of corals to bleach in the Indian Ocean where fatalities exceeded 20-30\% (Hoegh-Guldberg 1999). Such severe bleaching events have become increasingly common ever since (Hughes et al. 2003; Hoegh-Guldberg et al. 2007).

Carbon dioxide forms carbonic acid in sea water, increasing ocean acidity. The atmosphere already contains more $\mathrm{CO}_{2}$ than anytime in the last $800 \mathrm{Ka}$ (Lüthi et al. 2008) and $\mathrm{pH}$ has declined by $0.1 \mathrm{pH}$ units in a decade and will continue to do so (Feely et al. 2004; Doney et al. 2009). The ocean will eventually equilibrate when weathering of rocks on land catches up with inputs of $\mathrm{CO}_{2}$, and $\mathrm{pH}$ will return to its previous normal value of about 8.1. But the increase in $\mathrm{CO}_{2}$ is so rapid and so large that equilibration may take several thousand years, just as during the PETM. The effects on many calcifying organisms such as corals, molluscs and calcareous plankton may be severe owing to decreased ability to build their skeletons. Laboratory experiments with minute calcareous plankton showed abnormal and failed skeletal growth with reductions of only a few tenths of a $\mathrm{pH}$, well within the projected range owing to increasing $\mathrm{CO}_{2}$ (Riebesell 2004). Other experiments, however, have shown more variable results, with some species failing to calcify while others actually increased rates of calcification (Doney et al. 2009). Corals are likely to be particularly susceptible, however, which augurs poorly for the future of coral reefs (Hoegh-Guldberg et al. 2007). Acidification also affects other vital functions such as photosynthesis, nitrogen fixation and reproduction (Doney et al. 2009).

\section{(d) Synergies and feedbacks}

Exploitation, pollution and the rise of carbon dioxide interact in complex ways to effect physical, chemical and biological changes greater than would occur owing to the sum total of their independent effects. A major reason is the occurrence of positive feedbacks that speed up and magnify changes in oceanographic conditions (Rahmstorf et al. 2007). Summer sea ice is disappearing from the Arctic and sea level is rising much faster than expected from climate models because disappearance of summer ice decreases the Earth's albedo, which in turn increases the overall rate of global warming, which in turn melts ice faster (Stroeve et al. 2007). Vertical stratification is increasing because of surface warming, which decreases upwelling of cool, nutrient-rich waters so that surface waters warm even faster (Roemmich \& McGowan 1995), which in turn further accelerates warming as well as causing a drop in productivity of vast areas of the ocean (Polovina et al. 2008).

Similar nonlinearities occur because of positive feedbacks among biological factors, which in turn affect the resilience of organisms and ecosystems to environmental events (Scheffer et al. 2001; Knowlton 2004). This is especially apparent for the interactions among the myriad factors affecting the global decline of reef corals whose mass mortality in the past few decades threatens the very existence of coral reefs (Knowlton 1992; Hughes 1994; Kline et al. 2006; Smith et al. 2006; Hoegh-Guldberg et al. 2007; Knowlton \& Jackson 2008; Rasher \& Hay 2010). In some cases, overfishing of herbivorous fishes that graze on benthic algae allows population explosions of large, fleshy macroalgae that overgrow, smother or poison all but the fastest growing corals. In other cases, high temperatures cause coral bleaching and coral death. And in still other cases, outbreaks of disease reduce formerly great stands of branching acroporid corals to rubble.

But it is much more complicated than this. In the past, Caribbean coral reefs that suffered severe reef destruction by hurricanes recovered rapidly through strong coral recruitment and growth (Shinn 1976). Since the 1980s, however, reefs have failed to recover following hurricanes because previously reduced populations of herbivores fail to control population explosions of seaweeds on the newly bared substratum and previously reduced populations of corals are inadequate to produce sufficient recruits for coral recovery (Hughes 1994; Gardner et al. 2005). Macroalgae leak copious amounts of organic matter into the surrounding sea water, which increases microbial abundance including coral pathogens (Kline et al. 2006; Smith et al. 2006; Dinsdale et al. 2008; 
Marhaver et al. 2008). Sewage and excess nutrients may also fuel microbial growth and disease. Abundant macroalgae also overgrow and kill the crustose coralline algae, which are the preferred habitat for settling larvae of corals. Reefs that are severely overfished have higher incidence of disease and lower rates of recruitment and recovery following mass bleaching events (Sandin et al. 2008). Finally, ocean acidification is decreasing rates of coral calcification and therefore affecting coral growth. Scientists debate which factors are the most important agents of coral decline; but the argument is sterile because all of the factors are responsible (Pandolfi et al. 2005; Knowlton \& Jackson 2008; Hughes et al. 2010).

Harmful synergies also occur in estuaries and coastal seas where run-off of excess nutrients results in increased production of microbial plankton that increases abundance of pathogens that kill off the few surviving oysters so that recovery fails to occur even when run-off of excess nutrients is decreased (Jackson et al. 2001; Lotze et al. 2006). In general, once hypoxia has occurred, ecosystems appear to become increasingly susceptible to repeated hypoxic events (Conley et al. 2008).

\section{SCENARIOS FOR THE FUTURE OCEAN}

We can summarize the extent of human impacts on the oceans in stark terms. Humans have caused and continue to hasten the ecological extinction of desirable species and ocean ecosystems. In their place, we are witnessing population explosions of formerly uncommon species and novel ecosystems with concomitant losses in biodiversity and productivity for human use. Many of the newly abundant species, such as jellyfish in the place of fish and toxic dinoflagellates in the place of formerly dominant phytoplankton, are undesirable equivalents to rats, cockroaches and pathogens on the land. Moreover, there are good theoretical reasons and considerable empirical evidence to suggest that, once established, such newly established communities become stabilized owing to positive feedbacks among newly dominant organisms and their highly altered environments - which raises questions about whether unfavourable changes can be undone if we put our minds to it (Scheffer et al. 2001; Knowlton 2004; Jackson 2008; Hughes et al. 2010).

\section{(a) Projected trends}

Several trends for life in the oceans are clearly apparent if we do not act quickly to reduce overfishing, pollution and the rise of $\mathrm{CO}_{2}$. Most commercial wild fisheries will be lost and many prized species such as bluefin tuna may even go extinct. Surface waters will become increasingly warmer and more acidic, resulting in the further decline and possible extinction of most reef corals and other calcifying organisms. Warmer and lighter surface waters will strongly inhibit vertical mixing of nutrients to the surface and oxygen to deeper waters, resulting in the collapse in productivity in pelagic ecosystems and widespread hypoxia or anoxia below the increasingly stable thermocline, as occurred decades ago in the Black Sea (Rabalais et al. 2002). Widening dead zones around continents and other forms of pollution will make coastal waters too toxic for aquaculture and outbreaks of diseases will increase. Accelerated melting of polar ice sheets will release vast amounts of fresh water that will float along the ocean surface, further inhibiting vertical mixing and raising sea level. Sea level will rise and the intensity of storms will increase, threatening human populations and coastal ecosystems. Global biogeochemical cycles will be altered in increasingly uncertain ways.

Predictions are always risky, but it is difficult to imagine how all of these projected changes would not occur barring decisive action to reverse the trends or some global catastrophe to humanity. All of the trends are already in progress and continue to be measured by routine oceanographic observations. The oceans are becoming measurably warmer and more acidic and polar sea ice is measurably melting faster than expected from global climate models (Rahmstorf et al. 2007; Stroeve et al. 2007). Eutrophication, hypoxia and the numbers of dead zones are measurably increasing in quantity and size (Rabalais et al. 2002, 2007; Diaz \& Rosenberg 2008). Vertical mixing of the oceans is measurably decreasing with measurably great decreases in pelagic productivity (Roemmich \& McGowan 1995; Polovina et al. 2008). More and more fisheries have measurably collapsed with the concomitant ecological extinction of large fishery species (Jackson et al. 2001; Pauly et al. 2002; Jackson 2006, 2008; NRC 2006). Sea level is measurably rising at increasing rates and hurricanes are intensifying.

Thus, the question is not whether these trends will happen, but how fast they will happen, and what will be the consequences for the oceans and humanity. All of the predicted changes in oceanographic conditions exceed those associated with the ecological reorganization and extinctions of Caribbean species following the uplift of the Isthmus of Panama, and the rates and amounts of warming approach those associated with the PETM and other early Cenozoic and Mesozoic hyperthermal events (Wilson \& Norris 2001; Zachos et al. 2008; Kump et al. 2009). Previous episodes of deep-sea anoxia in the geological past were associated with mass extinctions of deep-sea marine species and reef corals (Thomas \& Shackleton 1996; Thomas 2007; Scheiber \& Speijer 2008; Zachos et al. 2008), and the global deep-sea anoxia at the end of the Permian was associated with the mass extinction of 95 per cent of the animal species on the planet (Erwin 2006; Knoll et al. 2007). Moreover, none of these past biological apocalypses was associated with a single dominant species that increasingly dominates the renewable resources, nutrient cycling and biogeochemical cycles of the planet (Vitousek et al. 1997; Wackernagel et al. 2002; Howarth et al. 2004). In light of everything we know about upheavals in the geological past, another great mass extinction appears inevitable.

\section{(b) How can we prevent the irreversible degradation of the oceans?}

There are too many people and too many changes have occurred to return the oceans to their pristine state. 
Moreover, any kind of resource use for food and energy has inevitable environmental costs. But present use is clearly unsustainable as measured by the human ecological footprint that has risen from about two billion people using roughly one-third to one-half of the Earth's renewable resources in 1950 to 6.8 billion people using more than 140 per cent of renewable resources today (Global Footprint Network 2010). So, we need to make the social, economic and political commitment to change, and then address simultaneously the three big drivers of ocean degradation: overfishing, pollution and the rise of $\mathrm{CO}_{2}$.

Overfishing is potentially reversible by simple changes in human behaviour, and we have the management tools to bring overfishing under control (Beddington et al. 2007; Hilborn 2007). Moreover, very few fisheries species have gone extinct. But progress has been inconsistent and spotty at best (Pauly et al. 2002, 2003; FAO 2008; Worm et al. 2009). Most coastal fisheries have declined or collapsed, and the ineffectiveness of international measures to stop pirate fishing or even to reduce the legal exploitation of critically endangered species of sharks and bluefin tuna (Safina \& Klinger 2008; Eilperin 2010) suggests that humans are incapable of such restraint on a global scale. The moratorium on whaling is an exception to the general pattern, but the moratorium is itself critically endangered (Kaufman \& Eilperin 2010). If present trends continue, large predatory fishes will be brought to the brink of extinction within the century, with major shifts in marine food webs and community composition that are already taking place. The list of species like cod that have failed to recover is growing, as is the number of coastal seas whose food webs are dominated by microbes and jellyfish (Jackson 2006, 2008).

Nutrient pollution is also potentially reversible with fundamental reforms in agricultural practice, including substantial restrictions on the use of fertilizers and sewage treatment of all animal wastes. Efforts to reduce nutrient run-off into estuaries like the Baltic and Chesapeake Bay have met with some modest success, although hypoxia may persist indefinitely even after run-off of nutrients is curtailed owing to the reworking of sediments that results in continuous nutrient pollution (Meyer-Reil \& Köster 2000; Rabalais et al. 2002). Regardless, the global trend in nutrient run-off to the oceans is sharply rising (Tilman et al. 2002; Clay 2004; Galloway et al. 2004; Dale \& Polasky 2007; Rabalais et al. 2007). Under these circumstances, the number and size of dead zones will increase to form continuous swaths for thousands of kilometres along continental coastlines within the century. Toxic blooms will also increase in size and frequency, and primary production will be increasingly dominated by the microbial loop, with catastrophic effects on fisheries and aquaculture (Jackson 2006).

The challenges for reducing greenhouse gas emissions are even more enormous. Nevertheless, rapid and considerable reductions could be achieved through a combination of economic incentives and taxes to reduce consumption coupled with an all-out commitment to developing more efficient energy production and alternative carbon-neutral technologies. The need for immediate action is all the more pressing because ocean warming and acidification will continue to increase for centuries because of the residual impact of emissions to date. However, even the most optimistic scenarios envision increases rather than decreases in the burning of fossil fuels for decades to come (Stern 2006). Thus, barring some miracle technology to sequester $\mathrm{CO}_{2}$ on a massive scale, warming and acidification will continue indefinitely.

None of these reforms will be possible without fundamental changes in personal expectations and the ways we obtain energy for everything we do. All of us are responsible and all of us will have to give up a lot to make a real difference. The alternative is a hothouse world, hundreds of millions, if not billions, of climate refugees, increasing global conflict for water, food and habitable places to live, and the end of any hope for a comfortable way of life. The problems are 99 per cent economic and political, not scientific, and we need no new scientific data to know what to do to put on the brakes and reverse the worst of the trends. The question is whether we can overcome our apathy, ignorance, corruption and greed to act responsibly, or wait for catastrophe to strike.

\section{REFERENCES}

Albins, M. A. \& Hixon, M. A. 2008 Invasive Indo-Pacific lionfish Pterois volitans reduce recruitment of Atlantic coral reef fishes. Mar. Ecol. Prog. Ser. 367, 233-238. (doi: 10.3354/meps07620)

Alter, S. E., Rynes, E. \& Palumbi, S. R. 2007 DNA evidence for historical population size and past ecological impacts of gray whales. Proc. Natl Acad. Sci. USA 104, $15162-$ 15 167. (doi:10.1073/pnas.0706056104)

Atkinson, A., Siegel, V., Pakhomov, E. \& Rothery, P. 2004 Long-term decline in krill stock and increase in salps in the Southern Ocean. Nature 432, 100-103. (doi:10. 1038/nature02996)

Azzarello, M. Y. \& Van Fleet, E. S. 1987 Marine birds and plastic pellets. Mar. Ecol. Prog. Ser. 37, 295-303. (doi:10.3354/meps037295)

Bartoli, G., Sarnthein, M., Weinelt, M., Erlenkeuser, H., Garbe-Schönberg, D. \& Lea, D. W. 2005 Final closure of Panama and the onset of northern hemisphere glaciation. Earth Planet. Sci. Lett. 237, 33-44. (doi:10.1016/j. epsl.2005.06.020)

Baum, J. K. \& Worm, B. 2009 Cascading top-down effects of changing oceanic predator abundances. F. Anim. Ecol. 78, 699-714. (doi:10.1111/j.1365-2656.2009.01531.x)

Baum, J. K., Myers, R. A., Kehler, D. G., Worm, B., Harley, S. J. \& Dohert, P. A. 2003 Collapse and conservation of shark populations in the northwest Atlantic. Science 299, 389-392. (doi:10.1126/science.1079777)

Beaugrand, G., Reid, P. C., Ibanez, F., Lindley, J. A. \& Edwards, M. 2002 Reorganization of North Atlantic marine copepod biodiversity and climate. Science 296, 1692-1694. (doi:10.1126/science.1071329)

Beddington, J. R., Agnew, D. J. \& Clark, C. W. 2007 Current problems in the management of marine fisheries. Science 316, 1713-1716. (doi:10.1126/science.1137362)

Booth, S. \& Zeller, D. 2005 Mercury, food webs, and marine mammals: implications of diet and climate change for human health. Environ. Health Perspect. 113, 521-526. (doi:10.1289/ehp.7603) 
Bralower, T. J. 2002 Evidence for surface water oligotrophy during the Late Paleocene thermal maximum: nannofossil assemblage data from Ocean Drilling Program Site 690, Maud Rise, Weddell Sea. Paleoceanography 17, 12pp. (doi:10.1029/2001PA000662)

Brierley, A. S. et al. 2002 Antarctic krill under sea ice: elevated abundance in a narrow band just south of ice edge. Science 295, 1890-1892. (doi:10.1126/science. 1068574)

Budd, A. F. \& Johnson, K. G. 1999 Origination preceding extinction during Late Cenozoic turnover of Caribbean reefs. Paleobiology 25, 188-200.

Burreau, S., Zebühr, Y., Broman, D. \& Ishaq, R. 2006 Biomagnification of PBDEs and PCBs in food webs from the Baltic Sea and the northern Atlantic Ocean. Sci. Total Environ. 366, 659-672.

Bush, B., Streeter, R. W. \& Sloan, R. J. 1989 Polychlorobiphenyl (PCB) congeners in striped bass (Morone saxatilis) from marine and estuarine waters of New York State determined by capillary gas chromatography. Arch. Environ. Contam. Toxicol. 19, 49-61. (doi:10.1007/ BF01059812)

Campbell, L. M., Norstrom, R. J., Hobson, K. A., Muir, D. C. G., Backus, S. \& Fisk, A. T. 2005 Mercury and other trace elements in a pelagic Arctic marine food web (Northwater Polynya, Baffin Bay). Sci. Total Environ. 351/352, 247-263.

Carlton, J. T. \& Geller, J. B. 1993 Ecological roulette: the global transport of nonindigenous marine organisms. Science 261, 78-82. (doi:10.1126/science.261.5117.78)

Carpenter, S. R., Caraco, N. F., Correll, D. L., Howarth, R. W., Sharpley, A. N. \& Smith, V. H. 1998 Nonpoint pollution of surface waters with phosphorous and nitrogen. Ecol. Appl. 8, 559-568. (doi:10.1890/10510761(1998)008[0559:NPOSWW]2.0.CO;2)

Carpi, A. 1997 Mercury from combustion sources: a review of the chemical species emitted and their transport in the atmosphere. Water Air Soil Pollut. 98, 241-254.

Christensen, V., Guenette, S., Heymans, J. J., Walters, C. J., Watson, R., Zeller, D. \& Pauly, D. 2003 Hundred-year decline of North Atlantic predatory fishes. Fish Fish. 4, 1-24. (doi:10.1046/j.1467-2979.2003.00103.x)

Clay, J. 2004 World agriculture and the environment: a commodity-by-commodity guide to impacts and practices. Washington, DC: Island Press.

Coates, A. G., Jackson, J. B. C., Collins, L. S., Cronin, T. M., Dowsett, H. J., Bybell, L. M., Jung, P. \& Obando, J. 1992 Closure of the Isthmus of Panama: the near-shore marine record of Costa Rica and western Panama. Geol. Soc. Am. Bull. 104, 814-828. (doi:10.1130/0016-7606(1992)104<0814:COTIOP $>2.3$. $\mathrm{CO} ; 2)$

Coleman, F. C., Figueira, W. F., Ueland, J. S. \& Crowder, L. B. 2004 The impact of United States recreational fisheries on marine fish populations. Science 305, 1958-1960. (doi:10.1126/science.1100397)

Conley, D. J., Carstensen, J., Vaquer-Sunyer, R. \& Duarte, C. M. 2008 Ecosystem thresholds with hypoxia. Hydrobiologia 629, 21-29. (doi:10.1007/s10750-009-9764-2)

Coté, I. M. \& Maljkovie, A. 2010 Predation rates of IndoPacific lionfish on Bahamian coral reefs. Mar. Ecol. Prog. Ser. 404, 219-225. (doi:10.3354/meps08458)

Cramer, K. L., Perryman, W. L. \& Gerrodette, T. 2008 Declines in reproductive output in two dolphin populations depleted by the yellowfin tuna purse-seine fishery. Mar. Ecol. Prog. Ser. 369, 273-285. (doi:10. 3354/meps07606)

Dale, V. H. \& Polasky, S. 2007 Measures of the effects of agricultural practices on ecosystem services. Ecol. Econ. 64, 286-296. (doi:10.1016/j.ecolecon.2007.05.009)
Daskalov, G. M., Grishen, A. N., Rodionov, S. \& Mihneva, V. 2007 Trophic cascades triggered by overfishing reveal possible mechanisms of ecosystem regime shifts. Proc. Natl Acad. Sci. USA 104, 10 518-10 523. (doi:10.1073/ pnas.0701100104)

Dayton, P. K., Thrush, S. F., Agardy, M. T. \& Hofman, R. J. 1995 Environmental effects of marine fishing. Aquat. Conserv. Mar. Freshw. Ecosyst. 5, 205-232. (doi:10. 1002/aqc.3270050305)

D'Croz, L. \& O'Dea, A. 2007 Variability in upwelling along the Pacific shelf of Panama and implications for the distribution of nutrients and chlorophyll. Estuar. Coast. Shelf Sci. 73, 325-340. (doi:10.1016/j.ecss.2007.01.013)

D’Croz, L. \& Robertson, D. R. 1997 Coastal oceanographic conditions affecting coral reefs on both sides of the Isthmus of Panama. Proc. 8th Int. Coral Reef Symp. 2, 2053-2058.

D’Croz, L., Del Rosario, J. B. \& Góndola, P. 2005 The effects of freshwater runoff on the distribution of dissolved inorganic nutrients and plankton in the Bocas del Toro Archipelago, Caribbean Panama. Caribb. F. Sci. 41, 414-429.

Derraik, J. G. B. 2002 The pollution of the marine environment by plastic debris: a review. Mar. Pollut. Bull. 44, 842-852. (doi:10.1016/S0025-326X(02)00220-5)

Diaz, R. J. \& Rosenberg, R. 2008 Spreading dead zones and consequences for marine ecosystems. Science 321, 926929. (doi:10.1126/science.1156401)

Dinsdale, E. A. 2008 Microbial ecology of four atolls in the Northern Line Islands. PLoS ONE 3, e1584. (doi:10. 1371/journal.pone.0001584)

Doney, S. C., Fabry, V. J., Feely, R. A. \& Kleypass, J. 2009 Ocean acidification: the other $\mathrm{CO}_{2}$ problem. Annu. Rev. Mar. Sci. 1, 169-192. (doi:10.1146/annurev.marine. 010908.163834)

Eilperin, J. 2010 Proposals to limit trading of fish rejected at global conference. The Washington Post. See http://www. washingtonpost.com/wp-dyn/content/article/2010/03/25/ AR2010032500782.html.

Erlandson, J. M. \& Rick, T. C. 2010 Archeology meets marine historical ecology: the antiquity of maritime cultures and human impacts on marine fisheries and ecosystems. Annu. Rev. Mar. Sci. 2, 231-251. (doi:10. 1146/annurev.marine.010908.163749)

Erwin, D. H. 2006 Extinction: how life on earth nearly ended 250 million years ago. Princeton, NJ: Princeton University Press.

Estes, J. A., Duggins, D. O. \& Rathburn, G. B. 1989 The ecology of extinctions in kelp forest communities. Conserv. Biol. 3, 252-264. (doi:10.1111/j.1523-1739. 1989.tb00085.x)

Estes, J. A., Tinker, M. T., Williams, T. M. \& Doak, D. F. 1998 Killer whale predation on sea otters linking oceanic and nearshore ecosystems. Science 282, 473-476. (doi: 10 . 1126/science.282.5388.473)

FAO 2008 The state of the world fisheries and aquaculture. Rome, Italy: Food and Agricultural Organization of the United Nations.

Feely, R. A., Sabine, C. L., Lee, K., Berelson, W., Kleypas, J., Fabry, V. J. \& Millero, F. J. 2004 Impact of anthropogenic $\mathrm{CO}_{2}$ on the $\mathrm{CaCO}_{3}$ system in the oceans. Science 305, 362-366. (doi:10.1126/science.1097329)

Field, D. B., Baumgartner, T. R., Charles, C. D., FerreiraBartrina, V. \& Ohman, M. D. 2006 Planktonic Foraminifera of the California Current reflect 20th-century warming. Science 311, 63-66. (doi:10.1126/science.1116220)

Frank, K. T., Petrie, B., Choi, J. S. \& Leggett, W. C. 2005 Trophic cascades in a formerly cod-dominated ecosystem. Science 308, 1621-1623. (doi:10.1126/science. 1113075) 
Galloway, G. N. et al. 2004 Nitrogen cycles: past, present and future. Biogeochemistry 70, 153-226. (doi:10.1007/ s10533-004-0370-0)

Gardner, T. A., Cote, I. M., Gill, J. A., Grant, A. \& Watkinson, A. R. 2003 Long-term region-wide declines in Caribbean corals. Science 301, 958-960. (doi:10.1126/science. 1086050)

Gardner, T. A., Cote, I. M., Gill, J. A., Grant, A. \& Watkinson, A. R. 2005 Hurricanes and Caribbean coral reefs: impacts, recovery patterns, and role in long-term decline. Ecology 86, 174-184. (doi:10.1890/04-0141)

Gerrodette, T. 2002 Tuna-dolphin issue. In Encyclopedia of marine mammals (eds W. F. Perrin, B. Wursig \& J. G. M. Thewissen), pp. 1269-1273. San Diego, CA: Academic Press.

Gibbs, S. J., Bralower, T. J., Brown, P. R., Zachos, J. C. \& Bybell, L. M. $2006 a$ Shelf-ocean calcareous phytoplankton assemblages across the Paleocene-Eocene thermal maximum: implications for global productivity gradients. Geology 34, 233-236. (doi:10.1130/G22381.1)

Gibbs, S. J., Brown, P. R., Sessa, J. A., Bralower, T. J. \& Wilson, P. A. $2006 b$ Nannoplankton extinction and origination across the Paleocene-Eocene thermal maximum. Science 314, 1770-1773. (doi:10.1126/science. 1133902)

Global Footprint Network 2010 World footprint. See http:// www.footprintnetwork.org/en/index.php/GFN/page/ world_footprint/.

Guzmán, H., Jackson, J. B. C. \& Weil, E. 1991 Short-term ecological consequences of a major oil spill on Panamanian subtidal reef corals. Coral Reefs 10, 1-12. (doi:10. 1007/BF00301900)

Hakansson, E. \& Thomsen, E. 2001 Asexual propagation in cheilostome Bryozoa: evolutionary trends in a major group of colonial animals. In Evolutionary patterns: growth, form and tempo in the fossil record (eds J. B. C. Jackson, S. Lidgard \& F. K. McKinney), pp. 326-347. Chicago, IL: University of Chicago Press.

Hardt, M. J. 2008 Lessons from the past: the collapse of Jamaican coral reefs. Fish Fish. 10, 1-16.

Haug, G. H. \& Tiedemann, R. 1998 Effect of the formation of the Isthmus of Panama on Atlantic Ocean thermohaline circulation. Nature 393, 673-676. (doi:10.1038/ 31447)

Hilborn, R. 2007 Moving to sustainability by learning from successful fisheries. $A M B I O$ 36, 296-303. (doi:10. 1579/0044-7447(2007)36[296:MTSBLF]2.0.CO;2)

Hoegh-Guldberg, O. 1999 Climate change, coral bleaching and the future of the world's coral reefs. Mar. Freshw. Res. 50, 839-866. (doi:10.1071/MF99078)

Hoegh-Guldberg, O. et al. 2007 Coral reefs under rapid climate change and ocean acidification. Science 318, 1737-1742. (doi:10.1126/science.1152509)

Howarth, R. W. 2004 Human acceleration of the nitrogen cycle: drivers, consequences, and steps towards solutions. Water Sci. Technol. 49, 7-13.

Hughes, T. P. 1994 Catastrophes, phase shifts, and largescale degradation of a Caribbean coral reef. Science 265, 1547-1551. (doi:10.1126/science.265.5178.1547)

Hughes, T. P. et al. 2003 Climate change, human impacts, and the resilience of coral reefs. Science 301, 929-933. (doi:10.1126/science.1085046)

Hughes, T. P., Graham, N. A. J., Jackson, J. B. C., Mumby, P. J. \& Steneck, R. S. In press. Rising to the challenge of sustaining coral reef resilience. Trends Ecol. Evol.

Ianelli, J. N., Barbeaux, S., Honkalchto, T., Kotzwicki, S., Aydin, K. \& Williamson, N. 2009 Assessment of the Walleye Pollock stock in the Eastern Bering Sea. Alaska Fisheries Science Center and National Marine Fisheries Service, 90pp. October Plan Team draft.
Jackson, J. B. C. 2001 What was natural in the coastal oceans? Proc. Natl Acad. Sci. USA 98, 5411-5418. (doi:10.1073/pnas.091092898)

Jackson, J. B. C. 2006 When ecological pyramids were upside down. In Whales, whaling, and ocean ecosystems (eds J. A. Estes, D. P. DeMaster, D. F. Doak \& T. M. Williams), pp. 27-37. Berkeley, CA: University of California Press.

Jackson, J. B. C. 2008 Evolution and extinction in the brave new ocean. Proc. Natl Acad. Sci. USA 105(Suppl. 1), 11 458-11 465. (doi:10.1073/pnas.0802812105)

Jackson, J. B. C. \& D'Croz, L. 1997 The ocean divided. In Central America: a natural and cultural history (ed. A. G. Coates), pp. 38-71. New Haven, CT: Yale University Press.

Jackson, J. B. C. \& Erwin, D. H. 2006 What can we learn about ecology and evolution from the fossil record? Trends Ecol. Evol. 21, 322-328. (doi:10.1016/j.tree. 2006.03.017)

Jackson, J. B. C. et al. 1989 Ecological effects of a major oil spill on Panamanian coastal marine communities. Science 243, 37-44. (doi:10.1126/science.243.4887.37)

Jackson, J. B. C., Budd, A. F. \& Coates, A. G. 1996 Evolution and environment in tropical America. New Haven, CT: Yale University Press.

Jackson, J. B. C. et al. 2001 Historical overfishing and the recent collapse of coastal ecosystems. Science 293, 629638. (doi:10.1126/science.1059199)

Johnson, K. G., Jackson, J. B. C. \& Budd, A. F. 2008 Caribbean reef development was independent of coral diversity over 28 million years. Science 319, 1521-1523. (doi:10. 1126/science.1152197)

Kaufman, M. \& Eilperin, J. 2010 Talks on reducing whale hunting break down. The Washington Post. See http:// www.washingtonpost.com/wp-dyn/content/article/2010/ 06/23/AR2010062300810_pf.html.

Keyl, F., Wolff, M., Argüelles, J., Mariátegui, L., Tafur, R. \& Yamashiro, C. 2008 A hypothesis on range expansion and spatio-temporal shifts in size-at-maturity of jumbo squid (Dosidicus gigas) in the eastern Pacific Ocean. Calif. Coop. Fish. Invest. Rep. 49, 119-128.

Kline, D. I., Kuntz, N. M., Breitbart, M., Knowlton, N. \& Rohwer, F. 2006 Role of elevated organic carbon levels and microbial activity in coral mortality. Mar. Ecol. Prog. Ser. 314, 119-125. (doi:10.3354/meps314119)

Knoll, A. H. 2003 Life on a young planet: the first three billion years of evolution on earth. Princeton, NJ: Princeton University Press.

Knoll, A. H., Bambach, R. K., Payne, J. L., Pruss, S. \& Fischer, W. W. 2007 Paleophysiology and the endPermian mass extinction. Earth Planet. Sci. Lett. 256, 295-313. (doi:10.1016/j.epsl.2007.02.018)

Knowlton, N. 1992 Thresholds and multiple stable states in coral reef community dynamics. Am. Zool. 32, 674-682.

Knowlton, N. 2001 The future of coral reefs. Proc. Natl Acad. Sci. USA 98, 5419-5425. (doi:10.1073/pnas. 091092998)

Knowlton, N. 2004 Multiple 'stable' states and the conservation of marine ecosystems. Prog. Oceanogr. 60, 387-396.

Knowlton, N. \& Jackson, J. B. C. 2008 Shifting baselines, local impacts, and climate change on coral reefs. PLoS Biol. 6, e54. (doi:10.1371/journal.pbio.0060054)

Kump, L. R., Bralower, T. J. \& Ridgwell, A. 2009 Ocean acidification in deep time. Oceanography 22, 94-107.

Le Télégramme 2009 Algues vertes: l'onde de choc. See http://www.letelegramme.com/ig/generales/fait-du-jour/ algues-vertes-un-debat-explosif-rapport-reactions-22-102009-619897.php.

Levitan, D. R. 2000 Optimal egg size in marine invertebrates: theory and phylogenetic analysis of the critical 
relationship between egg size and development time. Am. Nat. 156, 175-192.

Lewison, R. L., Crowder, L. B., Read, A. J. \& Freeman, S. A. 2004 Understanding impacts of fisheries bycatch on marine megafauna. Trends Ecol. Evol. 19, 598-604. (doi:10.1016/j.tree.2004.09.004)

Lotze, H. K. \& Worm, B. 2009 Historical baselines for large marine animals. Trends Ecol. Evol. 24, 254-262. (doi:10. 1016/j.tree.2008.12.004)

Lotze, H. K. et al. 2006 Depletion, degradation, and recovery potential of estuaries and coastal seas. Science 312, 1806-1809. (doi:10.1126/science.1128035)

Lüthi, D. et al. 2008 High-resolution carbon dioxide concentration record 650000-800000 years before present. Nature 453, 379-382. (doi:10.1038/nature06949)

Lynam, C. P., Gibbons, M. J., Axelsen, B. E., Sparks, C. A. J., Coetzee, J., Heywood, B. G. \& Brierley, A. S. 2006 Jellyfish overtake fish in a heavily fished ecosystem. Curr. Biol. 16, 492-493.

Marhaver, K. L., Edwards, R. A. \& Rohwer, F. 2008 Viral communities associated with healthy and bleaching corals. Environ. Microbiol. 10, 2277-2286. (doi:10.1111/ j.1462-2920.2008.01652.x)

McCall, A. D. In press. The sardine-anchovy puzzle. In Shifting baselines: historical perspectives on ocean fisheries (eds J. B. C. Jackson, K. Alexander \& E. Sala). Washington, DC: Island Press.

McClenachan, L. $2009 a$ Documenting loss of large trophy fish from the Florida keys with historical photographs. Conserv. Biol. 23, 636-643. (doi:10.1111/j.1523-1739. 2008.01152.x)

McClenachan, L. $2009 b$ Historical declines in goliath grouper in south Florida. Endang. Species Res. 7, 175-181. (doi:10.3354/esr00167)

McClenachan, L. \& Cooper, B. A. 2008 Extinction rate, historical population structure and ecological role of the Caribbean monk seal. Proc. R. Soc. B 275, 1351-1358. (doi:10.1098/rspb.2007.1757)

McClenachan, L., Jackson, J. \& Newman, M. 2006 Conservation implications of historic sea turtle nesting beach losses. Front. Ecol. Environ. 4, 290296. (doi:10.1890/1540-9295(2006)4[290:CIOHST]2. $0 . \mathrm{CO} ; 2)$

McEdward, L. R. 1997 Reproductive strategies of marine benthic invertebrates revisited: facultative feeding by planktotrophic larvae. Am. Nat. 150, 48-72.

McKinney, F. K. \& Jackson, J. B. C. 1989 Bryozoan evolution. Special Topics in Palaeontology. Boston, MA: Unwin-Hyman.

McPhee, D. P., Leadbitter, D. \& Skilleter, G. A. 2002 Swallowing the bait: is recreational fishing in Australia ecologically sustainable? Pac. Conserv. Biol. 8, 40-45.

Meinesz, A. 1999 Killer algae: the true tale of a biological invasion (transl. D. Simberloff). Chicago, IL: University of Chicago Press.

Meyer-Reil, L. A. \& Köster, M. 2000 Eutrophication of marine waters: effects on benthic microbial communities. Mar. Pollut. Bull. 41, 255-263. (doi:10.1016/S0025326X(00)00114-4)

Molnar, J. L., Gamboa, R. L., Revenga, C. \& Spalding, M. D. 2008 Assessing the global threat of invasive species to marine biodiversity. Front. Ecol. Environ. 6, 485-492. (doi:10.1890/070064)

Moore, C. J., Moore, S. L., Leecaster, M. K. \& Weisberg, S. B. 2001 A comparison of plastic and plankton in the north Pacific central gyre. Mar. Pollut. Bull. 42, $1297-$ 1300. (doi:10.1016/S0025-326X(01)00114-X)

Morell, V. 2009 Can science keep Alaska's Bering Sea pollock fishery healthy? Science 326, 1340-1341. (doi:10.1126/science.326.5958.1340)
Myers, R. A. \& Worm, B. 2003 Rapid worldwide depletion of predatory fish communities. Nature 423, 280-283. (doi:10.1038/nature01610)

Myers, R. A., Baum, J. K., Shepherd, T. D., Powers, S. P. \& Peterson, C. H. 2007 Cascading effects of the loss of apex predatory sharks from a coastal ocean. Science 315, 1846-1850. (doi:10.1126/science.1138657)

NOAA (National Oceanic and Atmospheric Administration) 2008 NOAA finds decline in pollock; recommends catch cut to council. See http://www.noaanews.noaa.gov/ stories2008/20081120_pollock.html.

NRC (National Research Council) 2002 Effects of trawling and dredging on seafloor habitat. Washington, DC: National Academy Press.

NRC (National Research Council) 2006 Dynamic changes in marine ecosystems: fishing, food webs, and future options. Washington, DC: National Academy Press.

O'Dea, A. 2006 Asexual propagation in the marine bryozoan. Cupuladria exfragamis. F. Exp. Mar. Biol. Ecol. 335, 312-322.

O'Dea, A. \& Jackson, J. B. C. 2002 Bryozoan growth mirrors contrasting seasonal regimes across the Isthmus of Panama. Palaeogeogr. Palaeoclimatol. Palaeolecol. 185, 77-94.

O’Dea, A. \& Jackson, J. B. C. 2009 Environmental change drove macroevolution in cupuladriid bryozoans. Proc. R. Soc. B 276, 3629-3634. (doi:10.1098/rspb. 2009.0844)

O'Dea, A., Herrera-Cubilla, A., Fortunato, H. \& Jackson, J. B. C. 2004 Life history variation in cupuladriid bryozoans from either side of the Isthmus of Panama. Mar. Ecol. Prog. Ser. 280, 145-161. (doi:10.3354/ meps280145)

O’Dea, A., Jackson, J. B. C., Fortunato, H., Smith, J. T., D'Croz, L., Johnson, K. G. \& Todd, J. 2007 Environmental change preceded Caribbean extinction by 2 million years. Proc. Natl Acad. Sci. USA 104, 5501-5506. (doi:10.1073/pnas.0610947104)

O'Dea, A., Jackson, J. B. C., Taylor, P. D. \& Rodriguez, F. 2008 Modes of reproduction in recent and fossil cupuladriid bryozoans. Palaeontology 51, 847-864.

Pandolfi, J. M. et al. 2003 Global trajectories of the long-term decline of coral reef ecosystems. Science 301, 955-958. (doi:10.1126/science.1085706)

Pandolfi, J. M. et al. 2005 Are U.S. coral reefs on the slippery slope to slime? Science 307, 1725-1726. (doi:10.1126/ science.1104258)

Parmesan, C. 2006 Ecological and evolutionary responses to recent climate change. Annu. Rev. Ecol. Evol. Syst. 37, 637-669. (doi:10.1146/annurev.ecolsys.37.091305. 110100)

Pauly, D., Christensen, V., Guénette, S., Pitcher, T. J., Sumaila, U. R., Walters, C. J., Watson, R. \& Zeller, D. 2002 Towards sustainability in world fisheries. Nature 418, 689-695. (doi:10.1038/nature01017)

Pauly, D., Alder, J., Bennett, E., Christensen, V., Tyedmers, P. \& Watson, R. 2003 The future for fisheries. Science 302, 1359-1361. (doi:10.1126/science.1088667)

Peterson, C. H., Rice, S. D., Short, J. W., Esler, D., Bodkin, J. L., Ballachey, B. E. \& Irons, D. B. 2003 Long-term ecosystem response to the Exxon Valdez oil spill. Science 302, 2082-2086. (doi:10.1126/science.1084282)

Piazzi, L., Ceccherelli, G. \& Cinelli, F. 2001 Threat to macroalgal diversity: effects of the introduced green alga Caulerpa racemosa in the Mediterranean. Mar. Ecol. Prog. Ser. 210, 149-159. (doi:10.3354/meps 210149)

Polovina, J. J., Howell, E. A. \& Abecassis, M. 2008 Ocean's least productive waters are expanding. Geophys. Res. Lett. 35, L03618. (doi:10.1029/2007GL031745) 
Rabalais, N. N., Turner, R. E. \& Wiseman Jr, W. J. 2002 Gulf of Mexico hypoxia, A.K.A. 'The Dead Zone'. Annu. Rev. Ecol. Syst. 33, 235-263. (doi:10.1146/ annurev.ecolsys.33.010802.150513)

Rabalais, N. N., Turner, R. E., Sen Gupta, B. K., Platon, E. \& Parsons, M. L. 2007 Sediments tell the history of eutrophication and hypoxia in the northern Gulf of Mexico. Ecol. Appl. 17, S129-S143. (doi:10.1890/060644.1)

Rahmstorf, S., Cazenave, A., Church, J. A., Hansen, J. E., Keeling, R. F., Parker, D. E. \& Somerville, R. C. J. 2007 Recent climate observations compared to projections. Science 316, 709. (doi:10.1126/science.1136843)

Rasher, D. B. \& Hay, M. E. 2010 Chemically rich seaweeds poison corals when not controlled by herbivores. Proc. Natl Acad. Sci. USA 107, 9683-9688. (doi:10.1073/ pnas.0912095107)

Revelle, R. \& Suess, H. E. 1957 Carbon dioxide exchange between atmosphere and ocean and the question of an increase of atmospheric $\mathrm{CO}_{2}$ during the past decades. Tellus 9, 18-27. (doi:10.1111/j.2153-3490.1957. tb01849.x)

Riebesell, U. 2004 Effects of $\mathrm{CO}_{2}$ enrichment on marine phytoplankton. F. Oceanogr. 60, 719-729. (doi:10.1007/ s10872-004-5764-z)

Roberts, C. M. 2007 The unnatural history of the sea. Washington, DC: Shearwater Books/Island Press.

Roemmich, D. \& McGowan, J. 1995 Climatic warming and the decline of zooplankton in the California Current. Science 267, 1324-1326. (doi:10.1126/science.267. 5202.1324)

Roughgarden, J. 1971 Density-dependent natural selection. Ecology 52, 453-468. (doi:10.2307/1937628)

Safina, C. \& Klinger, D. H. 2008 Collapse of bluefin tuna in the western Atlantic. Conserv. Biol. 22, 243-246. (doi:10. $1111 / j .1523-1739.2008 .00901 . x)$

Sandin, S. A. et al. 2008 Baselines and degradation of coral reefs in the northern Line Islands. PLoS ONE 3, e1548. (doi:10.1371/journal.pone.0001548)

Scheffer, M., Carpenter, S., Foley, J. A., Folke, C. \& Walker, B. 2001 Catastrophic shifts in ecosystems. Nature 413, 591-596. (doi:10.1038/35098000)

Scheiber, C. \& Speijer, R. P. 2008 Late Paleocene-Early Eocene Tethyan carbonate platform evolution-a response to long- and short-term paleoclimatic change. Earth Sci. Rev. 90, 71-102.

Shinn, E. A. 1976 Coral reef recovery in Florida and the Persian Gulf. Environ. Geol. 1, 241-254. (doi:10.1007/ $\mathrm{BF} 02407510)$

Simenstad, C. A., Estes, J. A. \& Kenyon, K. W. 1978 Aleuts, sea otters, and alternate stable-state communities. Science 200, 403-411. (doi:10.1126/science.200.4340. 403)

Smith, J. T. \& Jackson, J. B. C. 2009 Ecology of extreme faunal turnover of tropical American scallops. Paleobiology 35, 77-93. (doi:10.1666/07054.1)

Smith, J. T. \& Roy, K. 2006 Selectivity during background extinction: Plio-Pleistocene scallops in California. Paleobiology 32, 408-416. (doi:10.1666/05078.1)

Smith, J. E. et al. 2006 Indirect effects of algae on coral: algae-mediated, microbe-induced coral mortality. Ecol. Lett. 9, 835-845. (doi:10.1111/j.1461-0248.2006. 00937.x)

Southward, A. J. et al. 2005 Long-term oceanographic and ecological research in the western English Channel. Adv. Mar. Biol. 47, 1-105. (doi:10.1016/S00652881(04)47001-1)

Stachowicz, J. J., Terwin, J. R., Whitlatch, R. B. \& Osman, R. W. 2002 Linking climate change and biological invasions: ocean warming facilitates nonindigenous species invasions. Proc. Natl Acad. Sci. USA 99, $15497-15500$. (doi:10.1073/pnas.242437499)

Stanley, S. M. 1986 Anatomy of a regional mass extinction: Plio-Pleistocene decimation of the Western Atlantic bivalve fauna. Palaios 1, 17-36. (doi:10.2307/ 3514456)

Stern, N. 2006 The economics of climate change: the Stern report. New York, NY: Cambridge University Press.

Stevick, P. T. et al. 2003 North Atlantic humpback whale abundance and rate of increase four decades after protection from whaling. Mar. Ecol. Prog. Ser. 258, 263-273. (doi:10.3354/meps258263)

Stroeve, J., Holland, M. M., Meier, W., Scambos, T. \& Serreze, M. 2007 Arctic sea ice decline: faster than forecast. Geophys. Res. Lett. 34, LO9501.

Thomas, E. 1998 Biogeography of the later Paleocene benthic foraminiferal extinction. In Late PaleoceneEarly Eocene climatic and biotic events in the marine and terrestrial records (eds M.-P. Aubry, S. G. Lucas \& W. A. Berggren), pp. 214-235. New York, NY: Columbia University Press.

Thomas, E. 2007 Cenozoic mass extinctions in the deep sea: what perturbs the largest habitat on earth? In Large ecosystem perturbations: causes and consequences (eds S. Monechi, S. Coccioni \& M. R. Rampino), Geological Society of America Special Paper 424, pp. $1-23$.

Thomas, E. \& Shackleton, N. J. 1996 The PaleoceneEocene benthic foraminiferal extinction and stable isotope anomalies. In Correlation of the Early Paleogene in northwest Europe, vol. 101 (eds R. W. O. B. Knox, R. M. Cornfield \& R. E. Dunay), pp. 401-441. London, UK: Geological Society of London.

Tilman, D., Cassman, K., Matson, P., Naylor, R. \& Polasky, S. 2002 Agricultural sustainability and intensive production practices. Nature 418, 671-677. (doi:10.1038/ nature01014)

Todd, J. A., Jackson, J. B. C., Johnson, K. G., Fortunato, H. M., Heitz, A., Alvarez, M. \& Jung, P. 2002 The ecology of extinction: molluscan feeding and faunal turnover in the Caribbean Neogene. Proc. R. Soc. Lond. B 269, 571-577. (doi:10.1098/rspb.2001.1923)

Vance, R. R. 1973 On reproductive strategies in marine benthic invertebrates. Am. Nat. 107, 339-352.

Vaquer-Sunyer, R. \& Duarte, C. M. 2008 Thresholds of hypoxia for marine biodiversity. Proc. Natl Acad. Sci. USA 105, 15452-15457. (doi:10.1073/pnas. 0803833105)

Vitousek, P. M., Mooney, H. A., Lubchenco, J. \& Melillo, J. M. 1997 Human domination of earth's ecosystems. Science 277, 494-499. (doi:10.1126/science.277.5325. 494)

Wackernagel, M. et al. 2002 Tracking the ecological overshoot of the human economy. Proc. Natl Acad. Sci. USA 99, 9266-9271. (doi:10.1073/pnas.142033699)

Ward, P. \& Myers, R. A. 2005 Shifts in open-ocean fish communities coinciding with the commencement of commercial fishing. Ecology 86, 835-847. (doi:10.1890/ 03-0746)

Waycott, M. et al. 2009 Accelerating loss of seagrasses across the globe threatens coastal ecosystems. Proc. Natl Acad. Sci. USA 106, 12 377-12 381. (doi:10.1073/pnas. 0905620106)

Weiss, K. \& McFarling, U. L. 2006 Altered oceans. Los Angeles Times, 30 July 2006. See http://www.latimes. $\mathrm{com} /$ news/local/la-oceans-series, 1,468030.special.

Whitehead, H. 2002 Estimates of the current global population size and historical trajectory for sperm whales. Mar. Ecol. Prog. Ser. 242, 295-304. (doi:10.3354/ meps242295) 
Wilson, P. A. \& Norris, R. D. 2001 Warm tropical ocean surface and global anoxia during the mid-Cretaceous period. Nature 412, 425-429. (doi:10.1038/35086553)

Winston, J. E. 1977 Feeding in marine bryozoans. In Biology of bryozoans (eds R. M. Woolacott \& R. L. Zimmer), pp. 233-271. New York, NY: Academic Press.

Witman, J. D. \& Sebens, K. P. 1992 Regional variation in fish predation intensity: a historical perspective in the Gulf of Maine. Oecologia 90, 305-315. (doi:10.1007/ BF00317686)

Worm, B. et al. 2009 Rebuilding global fisheries. Science 325, 578-585. (doi:10.1126/science.1173146)
Zachos, J., Pagani, M., Sloan, L., Thomas, E. \& Billups, K. 2001 Trends, rhythms and aberrations in global climate. Science 292, 686-693. (doi:10.1126/science. 1059412)

Zachos, J. C., Dickens, G. R. \& Zeebe, R. E. 2008 An early Cenozoic perspective on greenhouse warming and carbon-cycle dynamics. Nature 451, 279-283. (doi:10. 1038/nature06588)

Zeidberg, L. D. \& Robison, B. H. 2007 Invasive range expansion by the Humboldt squid, Dosidicus gigas, in the eastern North Pacific. Proc. Natl Acad. Sci. USA 104, 12 948-12 950. (doi:10.1073/pnas.0702043104) 